\title{
Improved Reactivity in the Ring-Opening Polymerization of $\varepsilon$-Caprolactone with a Trinuclear Titanium(IV) Oxochloroneopentoxide as Initiator
}

\author{
Siddhartha O. K. Giese, ${ }^{a}$ Thiago A. da Silva, ${ }^{a}$ David L. Hughes, ${ }^{b}$ André Luis Rüdiger, ${ }^{a}$ \\ Eduardo L. de Sá, ${ }^{a}$ Sônia F. Zawadzki, ${ }^{a}$ Jaísa F. Soares*,a and Giovana G. Nunes ${ }^{a}$ \\ ${ }^{a}$ Departamento de Química, Universidade Federal do Paraná, Centro Politécnico, \\ Jardim das Américas, 81530-900 Curitiba-PR, Brazil \\ ${ }^{b}$ School of Chemistry, University of East Anglia, Norwich NR4 7TJ, UK
}

\begin{abstract}
The complex $\left[\mathrm{Ti}_{3}(\mathrm{O})(\mathrm{Cl})(\mathrm{ONep})_{9}\right]$ and two iron(II)-containing products, $\left[\mathrm{Fe}_{4} \mathrm{Cl}_{8}(\text { thf })_{6}\right]$ and $\left[\mathrm{Fe}_{2} \mathrm{Cl}_{3}\left(\mathrm{thf}_{6}\right]\left[\mathrm{FeCl}_{4}\right]\right.$, were synthesized by a redox reaction involving $\left[\mathrm{Ti}_{3}\left(\mathrm{O}^{\mathrm{P} P r}\right)_{11}\right]\left[\mathrm{FeCl}_{4}\right]$ and neopentanol; the structures of compounds $\left[\mathrm{Ti}_{3}(\mathrm{O})(\mathrm{Cl})(\mathrm{ONep})_{9}\right]$ and $\left[\mathrm{Fe}_{2} \mathrm{Cl}_{3}\left(\mathrm{thf}_{6}\right)\left[\mathrm{FeCl}_{4}\right]\right.$ have been confirmed by X-ray diffraction methods. Variable-temperature ${ }^{1} \mathrm{H}$ NMR analysis of $\left[\mathrm{Ti}_{3}(\mathrm{O})(\mathrm{Cl})(\mathrm{ONep})_{9}\right]$ revealed signals for three non-equivalent neopentoxides in the 1:1:1 integration ratio, indicating the maintenance of the trinuclear structure in solution. Alkoxide $\left[\mathrm{Ti}_{3}(\mathrm{O})(\mathrm{Cl})(\mathrm{ONep})_{9}\right]$ was employed as initiator in both bulk and solution polymerization of $\varepsilon$-caprolactone ( $\varepsilon$-CL) at various temperatures, monomer/initiator molar ratios and reaction times. $\left[\mathrm{Ti}_{3}(\mathrm{O})(\mathrm{Cl})(\mathrm{ONep})_{9}\right]$ produced poly( $\varepsilon$-caprolactone) in high yields, with molecular weights ranging from 7100 to $9800 \mathrm{~g} \mathrm{~mol}^{-1}$ and PDI (polydispersity index) values between 1.3 to 1.5 . The reactivity of $\left[\mathrm{Ti}_{3}(\mathrm{O})(\mathrm{Cl})(\mathrm{ONep})_{9}\right]$ in the ring-opening polymerization (ROP) of $\varepsilon$-CL was compared to those of $\left[\mathrm{Ti}_{3}\left(\mathrm{O}^{\mathrm{i}} \mathrm{Pr}_{11}\right]\left[\mathrm{FeCl}_{4}\right]\right.$ and $\left[\mathrm{Ti}(\mathrm{O} \cdot \mathrm{Pr})_{4}\right]$. The better polymerization reactivity shown by $\left[\mathrm{Ti}_{3}(\mathrm{O})(\mathrm{Cl})(\mathrm{ONep})_{9}\right]$ seems to be associated with structural features, as well as with the stronger Lewis basicity of -ONep over-O'Pr ligands and the maintenance of the trimetallic structure in the reaction media.
\end{abstract}

Keywords: $\varepsilon$-caprolactone, titanium(IV), trinuclear alkoxide, ring-opening polymerization, crystal structure analysis

\section{Introduction}

The catalytic activities of titanium compounds in polymerization processes aimed at the industrial production of polyethylene and polystyrene have been known since the $1950 \mathrm{~s},{ }^{1-3}$ while their more recent use in the synthesis of biodegradable polymers has increased for the last two decades. ${ }^{4}$ Such polymers, which include poly( $\varepsilon$-caprolactone) (PCL) and polylactide (PLA), find numerous biological and medical applications due to their biocompatible and bioabsorbable properties. ${ }^{5,6}$ Particularly, poly( $\varepsilon$-caprolactone) has been successfully applied in implanted biomaterials, cardiovascular and bone tissue engineering and slow-release drug systems. ${ }^{7,8}$

In the attempt to overcome difficulties in removing traces of metal-containing polymerization initiators from the reaction products, several complexes based on biocompatible elements such as $\mathrm{Zn}, \mathrm{Ca}, \mathrm{Fe}$, Ti and alkaline

*e-mail: jaisa@quimica.ufpr.br metals $^{9-13}$ have been evaluated recently in their ability to promote controlled ring-opening polymerization (ROP) of $\varepsilon$-caprolactone and lactides. Successful examples are provided by mononuclear complexes of iron(III) ${ }^{14}$ and zinc(II) $)^{15}$ with tridentate $\left(\mathrm{NNN}^{15}\right.$ and $\left.\mathrm{NNO}^{14}\right)$ ligands in the presence of alcohol, and by the binuclear titanium(IV) isopropoxide $\left[\mathrm{Ti}_{2}\left(\mathrm{O}^{\mathrm{i}} \mathrm{Pr}\right)_{5} \mathrm{~L}\right](\mathrm{L}=N, N$-di(salicylidene)2-hydroxyphenyl-methanediamine) in the polymerization of $L$ - and rac-LA in toluene solution, which revealed an excellent control over chain growth and produced polymers with a PDI (polydispersity index) value of $1.18 .{ }^{16}$

Simple titanium tetraalkoxides, $\left[\mathrm{Ti}(\mathrm{OR})_{4}\right]\left(\mathrm{OR}=\mathrm{OPr}^{\mathrm{n}}\right.$, $\left.\mathrm{O}^{\mathrm{t}} \mathrm{Bu}, \mathrm{O}^{\mathrm{n}} \mathrm{Bu}, \mathrm{OPh}\right),{ }^{17,18}$ initially employed in the polymerization of $\varepsilon$-caprolactone ( $\varepsilon$-CL) exhibited moderate activity but poor control over the ROP reaction. Recently reported theoretical calculations demonstrated that the length and bulk of the alkyl group strongly influence the way the ligand approaches the metal center and consequently interferes with the opening of the $\varepsilon$-CL ring by affecting the energy levels of the transition states. ${ }^{19}$ Besides these simple alkoxides, 
many other titanium(IV) compounds have been tested for the polymerization of cyclic esters; ${ }^{4}$ their reactivities have been rationalized on the basis of a possible modulation of metal Lewis acidity, which can be achieved by modifications in the nature of ligands, metal coordination number (4 to 6 ) and nuclearity of the metal complexes. ${ }^{10}$

In order to obtain polymers with high molecular mass and low polydispersity, the choice of metal complexes to act as initiators restricts the number of active sites by favoring mononuclear alkoxides containing ancillary bulky chelants. ${ }^{4,20}$ Another approach explores the higher activities of terminal over bridging alkoxides in the framework of polynuclear complexes. ${ }^{21}$ As an example, a remarkable reduction in polydispersion was achieved for the polymerization of $r a c-\mathrm{LA}^{22,23}$ with the use of a tripodal alkoxide ligand in the tetranuclear initiator $\left[\mathrm{Ti}_{4}(\mathrm{O} \mathrm{Pr})_{10} \mathrm{MeC}\left(\mathrm{CH}_{2} \mathrm{O}\right)_{3}\right]$. Another report of well-controlled ROP involved an octanuclear titanium(IV) oxoalkoxide, $\left[\mathrm{Ti}_{8} \mathrm{O}_{10}(\mathrm{O} \operatorname{Pr})_{6}\left(\mathrm{O}-2,4,6-\mathrm{Br}_{3} \mathrm{C}_{6} \mathrm{H}_{2}\right)_{8}\right]$, in the polymerization of $\varepsilon$-CL, giving polymers with ca. $15 \mathrm{~kg} \mathrm{~mol}^{-1}$ and a PDI of $1.22 .{ }^{24}$

The triangular unity of general formula $\mathrm{Ti}_{3}(\mathrm{O})(\mathrm{L})_{\mathrm{n}}$ is common in titanium(IV) alkoxide chemistry, with ligands (L) varying from simple alkoxides, ${ }^{25-27}$ carboxylates ${ }^{28}$ and catechol, ${ }^{29}$ to cyclopentadienyl ${ }^{30}$ derivatives. Some of these complexes, which are volatile or soluble in organic solvents, have been employed in the production of high density $\mathrm{TiO}_{2}$ thin films ${ }^{27}$ and nanocrystalline ceramic materials. ${ }^{29}$ However, despite the possibility to modulate the reactivity of the titanium(IV) centers in this type of complex by variation of ligands in both the $\mu_{2}$-bridged and terminal positions, to the best of our knowledge triangular titanium(IV) oxoalkoxides have not yet been evaluated in their potential to promote ROP processes.

The current work adds to our earlier reports on the reactivity of polynuclear iron(II/III) and titanium(IV) alkoxides ${ }^{31,32}$ and their use as initiators in the polymerization of cyclic esters. Good results have already been described for $\left[\mathrm{Ti}_{3}\left(\mathrm{O}^{\mathrm{i} P r}\right)_{11}\right]\left[\mathrm{FeCl}_{4}\right](\mathbf{A} \text {, Figure } \mathrm{S} 1)^{33}$ and $\left[\mathrm{FeCl}\left\{\mathrm{Ti}_{2}\left(\mathrm{O}^{\mathrm{i}} \mathrm{Pr}\right)_{9}\right\}\right]^{34}$ in the polymerization of both $\mathrm{rac}$-LA and $\varepsilon$-CL, with particularly promising data obtained for the lactide monomer. The reactivity of the ionic complex A was studied in bulk, while $\left[\mathrm{FeCl}\left\{\mathrm{Ti}_{2}(\mathrm{O} P \mathrm{Pr})_{9}\right\}\right]$ was employed in toluene solution and in bulk. Both initiators were shown to be thermally activated and the control over the polymerization process was dependent on the stability of the active species during the propagation steps. The need for further studies was evidenced by the difficulty in determining the extent of structural breakdown suffered by the trinuclear initiators during the reactions and in identifying the ROP active species in each case.
Looking for more efficient polynuclear ROP initiators based on titanium(IV), we carried out ligand exchange reactions involving complex $\mathbf{A}$ and neopentanol (HONep), cyclohexanol (HOCy) and methanol (HOMe). Different products were obtained, as HOCy gave a new $\left[\right.$ fac- $\left.\mathrm{Ti}(\mathrm{OCy})_{3}(\mathrm{thf})_{3}\right]\left[\mathrm{FeCl}_{4}\right]$ adduct and $\mathrm{MeOH}$ produced only a white solid insoluble in all solvents tested, indicating a polymeric composition. On the other hand, the ligand exchange reaction between $\mathbf{A}$ and HONep gave three products, $\left[\mathrm{Ti}_{3}(\mathrm{O})(\mathrm{Cl})(\mathrm{ONep})_{9}\right](\mathbf{B}),\left[\mathrm{Fe}_{4} \mathrm{Cl}_{8}(\mathrm{thf})_{6}\right](\mathbf{C})$ and $\left[\mathrm{Fe}_{2}(\mathrm{Cl})_{3}(\mathrm{thf})_{6}\right]\left[\mathrm{FeCl}_{4}\right](\mathbf{D})$, of which the titanium(IV)containing complex was tested as an initiator for both the bulk and solution polymerization of $\varepsilon$-CL. Compound $\mathbf{B}$ seemed to be a promising initiator because the methylene group of the ONep- ligand works as an spacer between the metal ion and the bulky tert-butyl ligand head; its presence could facilitate monomer access to the Lewis acid sites in the alkoxide complex when compared to the more hindered isopropyl groups present in $\mathbf{A}$. Results are compared in this work with those obtained from the parent alkoxide $\mathbf{A},{ }^{33}$ employed here for the first time as ROP initiator in toluene solution, and other similar complexes described in the literature.

\section{Experimental}

\section{General}

The manipulation and synthesis of the initiators and the polymerization tests were carried out under $\mathrm{N}_{2(\mathrm{~g})}$, using standard Schlenk techniques or a VAC/NEXUS 2000 glovebox. Solvents were dried and distilled under $\mathrm{N}_{2}$ prior to use. ${ }^{35}\left[\mathrm{Ti}\left(\mathrm{O}^{\mathrm{P} P r}\right)_{4}\right]$ (Merck) was distilled under vacuum and neopentanol (Alpha Aesar, 99\%) was used as received. The $\left[\mathrm{Ti}_{3}\left(\mu_{3}-\mathrm{O}^{\mathrm{i} P r}\right)_{2}(\mu-\mathrm{O} \mathrm{Pr})_{3}\left(\mathrm{O}^{\mathrm{i}} \mathrm{Pr}\right)_{6}\right]\left[\mathrm{FeCl}_{4}\right]$ initiator $(\mathbf{A})$ was prepared according to our earlier report. ${ }^{32} \varepsilon$-Caprolactone (Aldrich, 97\%) was dried with calcium hydride, distilled and stored under $\mathrm{N}_{2}$. After the polymerization reactions, PCL samples were precipitated using $\mathrm{CH}_{2} \mathrm{Cl}_{2}$ (Vetec, 99.5\%) and methanol (Vetec, 99.9\%).

\section{Instrumentation}

Microanalyses were carried out under argon at Medac Laboratories Ltd. (Chobham, Surrey, UK). Powder X-ray diffractograms were obtained on a Shimadzu XRD-600 machine operating at $40 \mathrm{kV}$ and $40 \mathrm{~mA}$, using MoK $\alpha$ radiation $(\lambda=0.71073 \AA$ ). Silicon powder was employed as internal reference. PCL samples dissolved in $\mathrm{CDCl}_{3}$ ( $0.1 \% \mathrm{tms})$ were also analyzed by ${ }^{1} \mathrm{H}$ nuclear magnetic resonance (NMR) spectroscopy on Bruker 400 and 
$600 \mathrm{MHz}$ spectrometers. Percentages of conversion $\left(\alpha_{\mathrm{c}}\right)$ and molecular weights were calculated from the monomer and polymer NMR signals, according to literature methods. ${ }^{36}$ Size exclusion chromatography was used to estimate the average and ponderal molecular weights $\left(\mathrm{M}_{\mathrm{n}}\right.$ and $\mathrm{M}_{\mathrm{w}}$, respectively), together with the polydispersion index (PDI) of the PCL samples, employing tetrahydrofuran (thf, $40^{\circ} \mathrm{C}$ ) as mobile phase. These analyses were carried out with an HPLC-GPC Waters 1515 chromatograph equipped with an isocratic pump and Supelco TSK-gel G 1000 HXL and $2000 \mathrm{HXL}(30 \mathrm{~cm} \times 7.8 \mathrm{~mm})$ columns coupled to refraction index Waters $2414\left(40{ }^{\circ} \mathrm{C}\right)$. Polystyrene (PS) standards were used to build the calibration curve and the molecular weights of the PCL samples were corrected by a factor of $0.56 .{ }^{37}$ Electron paramagnetic resonance (EPR) spectra were recorded from solid samples at $77 \mathrm{~K}$ with an $\mathrm{X}$-band Bruker EMX-Micro spectrometer. Glass transition and melting temperatures $\left(\mathrm{T}_{\mathrm{g}}\right.$ and $\left.\mathrm{T}_{\mathrm{m}}\right)$ of the polymers were determined by differential scanning calorimetry (DSC) using a Netzsch DSC 204 F1 MAIA calorimeter under continuous nitrogen purge and heating/cooling rates of $10{ }^{\circ} \mathrm{C} \mathrm{min}^{-1}$. Indium was used to calibrate the instrument. PCL samples (4 to $8 \mathrm{mg}$ ) were analyzed from ambient temperature to $150{ }^{\circ} \mathrm{C}$, maintained for $5 \mathrm{~min}$ in isothermal condition, cooled to $-120^{\circ} \mathrm{C}$, kept for $5 \mathrm{~min}$ in isothermal condition and heated up again to $150^{\circ} \mathrm{C}$.

\section{Single-crystal X-ray diffraction analyses of complexes B and $\mathbf{D}$}

Data were collected on a Bruker D8 Venture diffractometer equipped with a Photon-100 CMOS detector, a graphite monochromatic radiation source $(\mathrm{MoK} \alpha, \lambda=0.71073 \AA$ ) and a Kryoflex II cooling device. Suitable crystals of B (colorless blocks, ca. $0.75 \times 0.55 \times 0.35 \mathrm{~mm}$ ) and $\mathbf{D}$ (yellow blocks, ca. $0.34 \times 0.32 \times 0.31 \mathrm{~mm}$ ) were selected under mineral oil, mounted on a MicroMount ${ }^{\mathrm{TM}} 100 \mu \mathrm{M}$ (MiTeGen) under dinitrogen and cooled to $100 \mathrm{~K}$. Cell dimensions were determined based on 'observed' reflections $\left(I>2 \sigma_{1}\right)$. Data were processed with the APEX2 program..$^{38}$ The structure of $\mathbf{B}$ was confirmed using direct methods in the SHELXS software ${ }^{39}$ and refined (in SHELXL) $)^{40}$ by full-matrix least-squares methods on $F^{2}$. Atoms other than hydrogen were refined with anisotropic thermal parameters. At the conclusion of the refinement of $\mathbf{B}, \mathrm{wR}_{2}=0.100$ and $\mathrm{R}_{1}=0.039$ for all 11747 reflections weighted $\mathrm{w}=\left[\sigma^{2}\left(\mathrm{~F}_{\mathrm{o}}^{2}\right)+(0.0537 \mathrm{P})^{2}+1.9704 \mathrm{P}\right]^{-1}$ with $\mathrm{P}=\left(\mathrm{F}_{\mathrm{o}}^{2}+2 \mathrm{~F}_{\mathrm{c}}^{2}\right) / 3$; for the 'observed' data only, $\mathrm{R}_{1}=0.038$. In the final difference map, the highest peak (ca. 0.64 e. $\AA^{-3}$ ) was close to $\mathrm{H}(11 \mathrm{~B})$ of the toluene solvent molecule. The structure of $\mathbf{D}$ was determined by the intrinsic phasing routines in the SHELXT ${ }^{41}$ program and refined by full-matrix least-squares methods, on $F^{2}$ 's, with the SHELXL software. ${ }^{40}$ Cell dimensions indicated an orthorhombic cell, but structure determination (in P1) suggested that the cell was monoclinic with $\beta=90.040(3)^{\circ}$; this was confirmed in the refinement process. Also during the course of refinement, it became apparent that the crystal was twinned, and on inclusion of the TWIN and BASF instructions, refinement converged swiftly and satisfactorily. Disorder in one thf ligand of a methylene group over two orientations was resolved. The non-hydrogen atoms (except for the components of the disordered group) were refined with anisotropic thermal parameters. Hydrogen atoms of both structures (B and $\mathbf{D})$ were included in idealized positions and their isotropic displacement parameter, $\mathrm{U}_{\mathrm{iss}}$, values were set to ride on the equivalent anisotropic displacement parameter, $\mathrm{U}_{\mathrm{eq}}$, values of the parent carbon atoms. At the conclusion of the refinement of $\mathbf{D}, w \mathrm{R}_{2}=0.071$ and $\mathrm{R}_{1}=0.034$ for all 8349 reflections weighted $\mathrm{w}=\left[\sigma^{2}\left(\mathrm{~F}_{\mathrm{o}}^{2}\right)+(0.0299 \mathrm{P})^{2}+3.840 \mathrm{P}\right]^{-1}$ with $\mathrm{P}=\left(\mathrm{F}_{\mathrm{o}}^{2}+2 \mathrm{~F}_{\mathrm{c}}{ }^{2}\right) / 3$; for the 'observed' data only, $\mathrm{R}_{1}=0.030$. In the final difference map, the highest peak (ca. $0.73 \mathrm{e} . \AA^{-3}$ ) was close to the disordered region of the thf ligand. Diagrams were made using the ORTEP-3 software. . $2,43^{2}$

Reaction between $\left[\mathrm{Ti}_{3}\left(\mu_{3}-\mathrm{O} \mathrm{Pr}\right)_{2}\left(\mu-\mathrm{O}^{\prime} \mathrm{Pr}\right)_{3}(\mathrm{O} \mathrm{Pr})_{6}\right]\left[\mathrm{FeCl}_{4}\right](\mathbf{A})$ and neopentanol

A mixture of $\left[\mathrm{Ti}_{3}\left(\mu_{3}-\mathrm{O}^{\mathrm{i}} \mathrm{Pr}\right)_{2}\left(\mu-\mathrm{O}^{\mathrm{i}} \mathrm{Pr}\right)_{3}\left(\mathrm{O}^{\mathrm{i}} \mathrm{Pr}\right)_{6}\right]\left[\mathrm{FeCl}_{4}\right](\mathbf{A})$ $(1.04 \mathrm{~g}, 1.05 \mathrm{mmol})$ and neopentanol $(3.84 \mathrm{~g}, 43.6 \mathrm{mmol})$ in $30 \mathrm{~mL}$ of toluene was heated to $50^{\circ} \mathrm{C}$ for $24 \mathrm{~h}$ producing a dark yellow solution. The mother liquor was partially evaporated under vacuum and cooled to $-20{ }^{\circ} \mathrm{C}$, giving colorless crystals $\left(0.42 \mathrm{~g}, 38 \%\right.$ yield based on $\left.\mathrm{C}_{45} \mathrm{H}_{99} \mathrm{ClO}_{10} \mathrm{Ti}_{3}, \mathbf{B}\right)$. The filtrate was cooled again to $-20^{\circ} \mathrm{C}$, giving $0.84 \mathrm{~g}$ of a polycrystalline yellow solid, which was recrystallized from thf:hexane (1:2) to give $0.45 \mathrm{~g}$ of a mixture of two types of crystals (colorless $\mathbf{C}, \mathrm{C}_{24} \mathrm{H}_{96} \mathrm{Cl}_{8} \mathrm{Fe}_{4} \mathrm{O}_{6}$, and yellow $\mathbf{D}$, $\mathrm{C}_{24} \mathrm{H}_{48} \mathrm{Cl}_{3} \mathrm{Fe}_{2} \mathrm{O}_{6} \cdot \mathrm{FeCl}_{4}$ ). Product $\mathbf{B}$ was soluble in toluene, hexane and dichloromethane, but insoluble in thf and dimethoxyethane (glyme), while the mixture of $\mathbf{C}$ and $\mathbf{D}$ was soluble in toluene and thf but insoluble in hexane, isopropanol and glyme. Found for B: C, 57.91; H, 10.86\%; $\mathrm{Ti}_{3} \mathrm{O}_{10} \mathrm{ClC}_{45} \mathrm{H}_{99}$ requires: C, 58.29; $\mathrm{H}, 10.06 \%$.

\section{Polymerization reactions and kinetic studies}

Polymerization assays were conducted at least in duplicate with varying temperature, reaction time and initiator/monomer rate. Alkoxides $\mathbf{A}$ and $\mathbf{B}$ were both employed in the polymerization of $\varepsilon$-CL in toluene solution, while only $\mathbf{B}$ was tested for polymerization in bulk because 
results with A have already been reported by our group. ${ }^{33}$ Yields were calculated from the expected mass of products based on $100 \%$ of monomer conversion.

\section{Polymerization in solution}

$1.0 \mathrm{~mL}$ of toluene and the proper amount of initiator were mixed in a Schlenk tube and received the addition of $1.0 \mathrm{~g}(8.8 \mathrm{mmol})$ of $\varepsilon$-CL. The reaction mixture was heated to the desired temperature for a pre-established time under magnetic stirring. Toluene was subsequently removed under vacuum and $10 \mathrm{mg}$ of the powdery polymer was removed and redissolved in $\mathrm{CDCl}_{3}$ to be analyzed. The remaining product was then dissolved in dichloromethane $(1.0 \mathrm{~mL})$, precipitated with cold methanol $(1: 10 \mathrm{v} / \mathrm{v})$ and dried under vacuum to constant weight.

\section{Kinetic studies}

Polymerization reactions were performed in bulk for comparison with previous results. ${ }^{33}$ Briefly, the alkoxide $\left[\mathrm{Ti}_{3}\left(\mu_{3}-\mathrm{O}\right)\left(\mu_{3}-\mathrm{Cl}\right)(\mu-\mathrm{ONep})_{3}(\mathrm{ONep})_{6}\right](\mathbf{B})$ was dissolved directly in $1.00 \mathrm{~g}$ of the monomer in an $\varepsilon-\mathrm{CL} / \mathbf{B}$ ratio of 500 and warmed up to the desired temperatures. Several aliquots were taken at pre-established times from the reaction mixtures, cooled immediately to $0{ }^{\circ} \mathrm{C}$, and then dissolved in $\mathrm{CDCl}_{3}$ to be analyzed by ${ }^{1} \mathrm{H}$ NMR spectroscopy. Monomer conversion was monitored by comparison of the resonance signals at $\delta=2.31 \mathrm{ppm}\left(-\mathrm{CH}_{2}-\right.$ for the PCL) and $2.64 \mathrm{ppm}$ $\left(-\mathrm{CH}_{2}-\right.$ for $\left.\varepsilon-\mathrm{CL}\right)$.

\section{Results and Discussion}

\section{Synthesis}

The alcoholysis reaction involving $\left[\mathrm{Ti}_{3}\left(\mu_{3}-\mathrm{O}^{i} \mathrm{Pr}\right)_{2}\left(\mu-\mathrm{O}^{i} \mathrm{Pr}\right)_{3}\left(\mathrm{O}^{\mathrm{P}} \mathrm{Pr}\right)_{6}\right]\left[\mathrm{FeCl}_{4}\right](\mathbf{A})$ and neopentanol was carried out in toluene in 1:11 (stoichiometric) and 1:44 molar proportions. Both reactions were fully reproducible and gave the same products and yields. X-ray diffraction analysis of the crystals revealed partial reduction of iron(III) and metal segregation in different products. Two crystalline products of this reaction were structurally characterized, one neutral, homometallic titanium(IV) alkoxide (complex B) and an ionic iron(II)/(III) halide-tetrahydrofuran adduct (product D).

\section{Characterization of the titanium-containing product (complex B)}

Results of the X-ray structural analysis of $\left[\mathrm{Ti}_{3}\left(\mu_{3}-\mathrm{O}\right)\left(\mu_{3}-\right.\right.$ $\left.\mathrm{Cl})(\mu-\mathrm{ONep})_{3}(\mathrm{ONep})_{6}\right](\mathbf{B})$ were described earlier by Boyle et al. ${ }^{44}$ after attempts to synthesize the homoleptic titanium tetraneopentoxide, “Ti(ONep) $)_{4}$, from $\mathrm{NaONep}_{\text {and }} \mathrm{TiCl}_{4}$ in toluene. In that previous work, according to the authors, one of the crystals isolated from the reaction mixture consisted of $\mathbf{B}$. A satisfactory structural model was then proposed from the X-ray diffraction data, but difficulties caused by ligand fluxionality and positional disorder limited both the determination and the anisotropic refinement of models for some of the disordered -ONep ligands. Additional characterization (by ${ }^{1} \mathrm{H}$ NMR and Fourier transform infrared (FTIR) spectroscopies) of the bulk material obtained from the reaction mixture indicated that more than one product had been formed; no further characterization and no improved synthesis of $\mathbf{B}$ were reported. ${ }^{44}$

The present work describes a new, reproducible method to obtain crystalline $\mathbf{B}$ in high purity and good reaction yield. In this case, crystals gave quality X-ray diffraction data at low temperature $(100 \mathrm{~K})$, from which a precise structural model has been determined. Table S1 (Supplementary Information) presents data collection and structure refinement information, while Table S2 contains selected molecular dimensions (bond lengths and angles). The X-ray diffraction analysis established the replacement of isopropoxide (from $\mathbf{A}$ ) by neopentoxide (in $\mathbf{B}$ ), confirming the formation of the titanium(IV) analog of $\left[\mathrm{Zr}_{3}\left(\mu_{3}-\mathrm{O}\right)\right.$ $\left.\left(\mu_{3}-\mathrm{Cl}\right)(\mu-\mathrm{ONep})_{3}(\mathrm{ONep})_{6}\right]^{45}$ The structure of $\mathbf{B}$ (Figure 1) contains the planar $\left\{\mathrm{Ti}_{3} \mathrm{O}_{3}\right\}$ ring moiety found in a number of other trinuclear transition metal complexes, in this case with triply-bridging oxo and chloride ligands occupying opposite sides of the triangular plane formed by the metal centers.

Spectroscopic studies and elemental analysis (Experimental section) carried out for $\mathbf{B}$ in the present work indeed confirm the isolation of a high purity product. The FTIR spectrum shows strong absorptions in the range of $1385-1360 \mathrm{~cm}^{-1}$ attributed to the neopentyl skeleton, together with signals in the $900-1100 \mathrm{~cm}^{-1}$ region assigned to $v(\mathrm{C}-\mathrm{O})$ and medium intensity absorptions at 628 and $466 \mathrm{~cm}^{-1}$ for $v(\mathrm{Ti}-\mathrm{O})$ (Figure S2). ${ }^{44,46,47}$ Additionally, $\mathrm{X}$-band EPR analysis of complex $\mathbf{B}$ in the solid state at $77 \mathrm{~K}$ did not give any signal that could indicate the presence of iron(III) impurities.

Variable-temperature ${ }^{1} \mathrm{H}$ NMR experiments in toluene- $d_{8}$ suggest that the triangular $\mathrm{Ti}_{3}$ framework of $\mathbf{B}$ is kept in solution. Accordingly, the spectrum at $303 \mathrm{~K}$ shows only two sets of broad signals centered at 0.92 and $3.97 \mathrm{ppm}$, assigned respectively to the methyl and methylene hydrogen nuclei of the neopentyl groups (Figure 2) ${ }^{44}$ and indicates the presence of a fluxional chemical species in solution. The low resolution of these signals was attributed to the rapid intramolecular exchange of terminal and bridging alkoxide groups at this temperature. ${ }^{48,49}$

As the temperature was gradually decreased to 273 and 


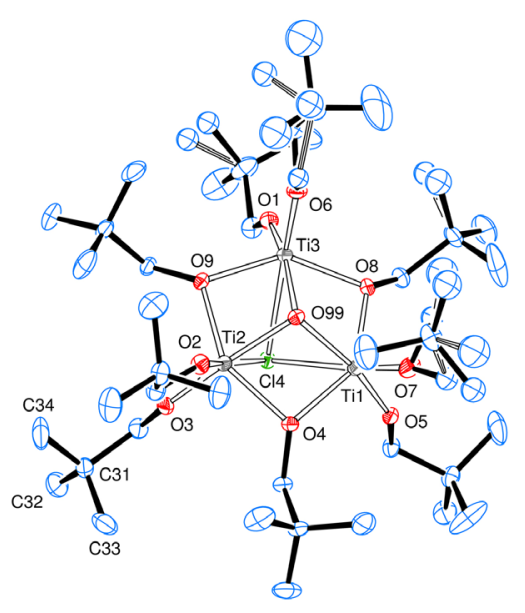

Figure 1. ORTEP $P^{42,43}$ representation of the $\left[\mathrm{Ti}_{3}\left(\mu_{3}-\mathrm{O}\right)\left(\mu_{3}-\mathrm{Cl}\right)\right.$ $\left.(\mu-\mathrm{ONep})_{3}(\mathrm{ONep})_{6}\right]$ molecule in $\mathbf{B}$.

then to $243 \mathrm{~K}$, spectral resolution improved and revealed three signals for the methylene group at 3.93, 4.17 and $4.44 \mathrm{ppm}$ (1:1:1 ratio), consistent with three distinct types of -ONep ligands. The solid state X-ray structure of $\mathbf{B}$ (Figure 1) shows three bridging $\left(\mu_{2}\right)$ and six terminal ONep ligands, while a thorough analysis of the structural data reveals that the plane defined by the $\mathrm{Ti}_{3}$ triangle creates two different chemical environments for the terminal ONep ligands located above and below the plane. Therefore, the three magnetically non-equivalent neopentoxide groups revealed by ${ }^{1} \mathrm{H}$ NMR analysis correspond to the $\mu_{2}$ and the two types of terminal ONep, and this is fully compatible with the maintenance of the solid state structure when $\mathbf{B}$ is dissolved in toluene. It is possible that the short and essentially equivalent $\mathrm{Ti}-\mu_{3}-\mathrm{O}$ bonds (average length $1.939 \AA$ in B) help to stabilize the triangular framework. This result has also been described for the hafnium alkoxide $\left[\mathrm{Hf}_{3}\left(\mu_{3}-\mathrm{O}\right)\left(\mu_{3}-\mathrm{ONep}\right)(\mu-\mathrm{ONep})_{3}(\mathrm{ONep})_{6}\right]$, which presents ${ }^{1} \mathrm{H}$ NMR signals in $\mathrm{CDCl}_{3}$ with an integration ratio of 1:3:3:3 from the bridging $\mu_{3}-\mathrm{OR}, \mu-\mathrm{OR}$ and two different types of terminal ONep ligands. ${ }^{50}$

${ }^{1} \mathrm{H}$ NMR signal resolution, although not complete, has also been observed in the methyl resonance region of Figure 2 (0.8 to $1.0 \mathrm{ppm}$ ). In this case, a residual signal for the fluxional species at ca. $0.92 \mathrm{ppm}$ is still seen in the spectrum, and its overlap with one of the slow exchange species gives an integral ratio of 1:3:1 even at $243 \mathrm{~K}$. Despite this, the analogous behavior of the $-\mathrm{CH}_{2}-$ and $-\mathrm{CH}_{3}$ resonances strongly suggests a similar conclusion. The attempt to further decrease the solution temperature led to the crystallization of $\mathbf{B}$ from the solution.

\section{Characterization of products $\mathbf{C}$ and $\mathbf{D}$}

After isolation of $\mathbf{B}$, all attempts to crystallize the iron-
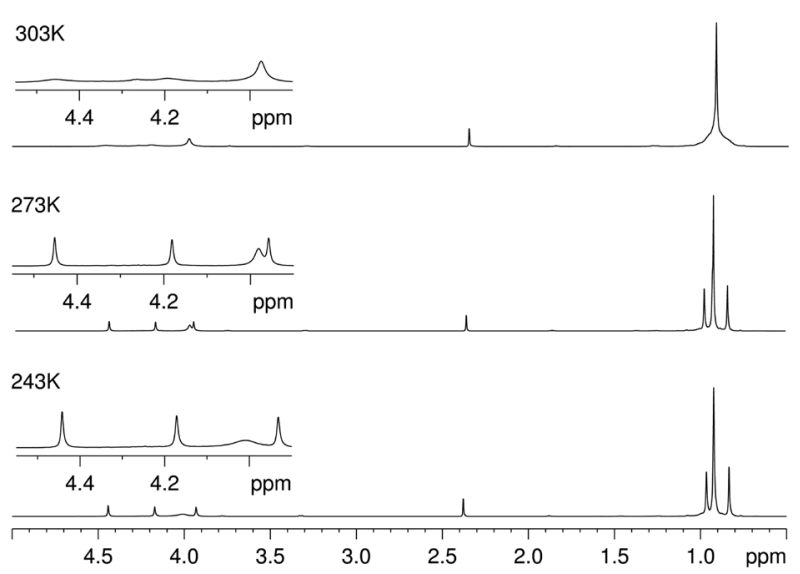

Figure 2. ${ }^{1} \mathrm{H}$ NMR spectra $\left(600.13 \mathrm{MHz}\right.$, toluene- $\left.d_{8}\right)$ of $\mathrm{B}\left(0.02 \mathrm{~mol} \mathrm{~L}^{-1}\right)$ at $303 \mathrm{~K}$ (top), $273 \mathrm{~K}$ (middle) and $243 \mathrm{~K}$ (bottom).

containing product directly from the mother liquor were unfruitful, producing viscous yellow oil when all solvent was removed under vacuum. The infrared spectrum of this oil revealed the presence of neopentyl (bands at 804, 862, $1022,1085 \mathrm{~cm}^{-1}$ ) and a strong absorption at $3444 \mathrm{~cm}^{-1}$ attributed to $\mathrm{v}(\mathrm{O}-\mathrm{H}){ }^{51}$ The EPR spectrum, in turn, showed a complex pattern suggesting a mixture of products (Figure S3a). In one occasion, the oil was dissolved in thf and received an overlayer of hexane (1:2). After a few days at room temperature, colorless crystals of product $\mathbf{C}$, together with few yellow crystals of product $\mathbf{D}$, were obtained. The IR spectrum of this mixture did not show bands corresponding to alkoxide groups, nor the $\mathrm{v}(\mathrm{O}-\mathrm{H})$ band in the $3400 \mathrm{~cm}^{-1}$ region (Figure S3b). Strong $v(C-C)$ and $v(C-O-C)$ signals at $935,997,1024$ and $1068 \mathrm{~cm}^{-1}$, on the other hand, agree with the incorporation of thf ligands in both complexes. ${ }^{52}$

The unit cell refinement carried out for $\mathbf{C}$ showed it to correspond to the well-known $\left[\mathrm{Fe}_{4}{ }_{4} \mathrm{Cl}_{8}\left(\mathrm{thf}_{6}\right)_{6}\right]$ complex, ${ }^{53,54}$ commonly obtained from thf solutions of iron(II) chloride; this indicates reduction of the iron(III) centers by the alcohol in the initial reaction steps. ${ }^{55}$ This complex has been isolated from the reduction of $\mathrm{FeCl}_{3}$ in presence of strong Lewis bases,${ }^{53}$ which is in accordance with the presence of alkoxides in the toluene/alcohol reaction medium.

Crystals of $\mathbf{D}$, in turn, were isolated as a byproduct and contain an ionic iron(II)/(III) complex (Figure 3). Selected crystallographic data and bond dimensions are listed in Tables 1 and 2.

In $\mathbf{D}$, the two iron(II) centers, each with regular octahedral coordination, are connected through a triangular face formed by the three bridging chlorides. The average $\mathrm{Fe}-(\mu-\mathrm{Cl})$ bond distance and $\mathrm{Fe}-(\mu-\mathrm{Cl})-$ Fe angle are $2.478 \AA$ and $74.98^{\circ}$, respectively, which are in accordance with other $\left[\mathrm{Fe}_{2}(\mu-\mathrm{Cl})_{3}(\text { thf })_{6}\right]^{+}$cations described in the literature. ${ }^{56,57} \mathrm{As}$ in $\mathbf{A}$, the anion present in 


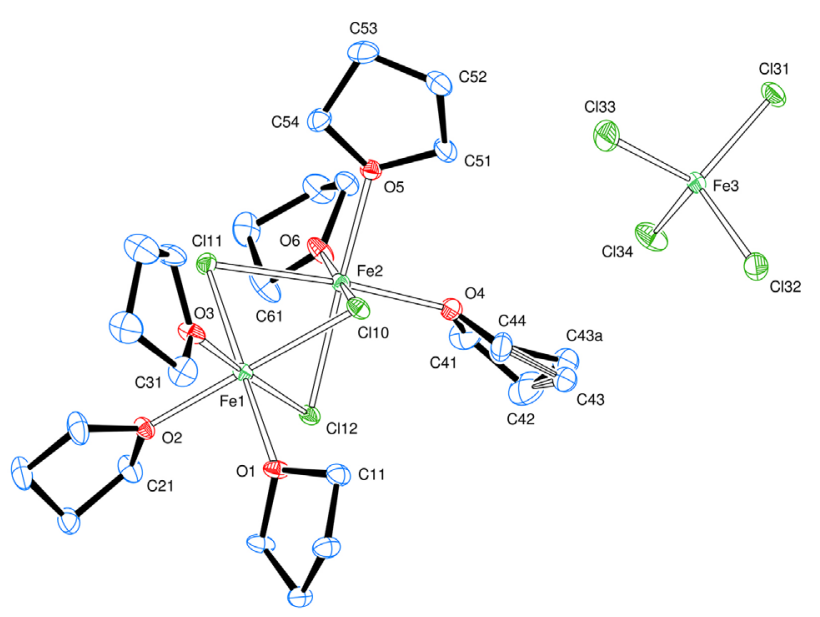

Figure 3. ORTEP $P^{42,43}$ representation of product $\mathbf{D},\left[\mathrm{Fe}_{2}(\mu-\mathrm{Cl})_{3}(\mathrm{thf})_{6}\right]$ $\left[\mathrm{FeCl}_{4}\right]$.

Table 1. Crystal and structure refinement data for $\left[\mathrm{Fe}_{2}(\mu-\mathrm{Cl})_{3}(\text { thf })_{6}\right]$ $\left[\mathrm{FeCl}_{4}\right](\mathbf{D})$

\begin{tabular}{lc}
\hline & $\mathbf{D}$ \\
\hline Empirical formula & $\mathrm{C}_{24} \mathrm{H}_{48} \mathrm{Cl}_{3} \mathrm{Fe}_{2} \mathrm{O}_{6} \cdot \mathrm{FeCl}_{4}$ \\
Formula weight / $\left(\mathrm{g} \cdot \mathrm{mol}^{-1}\right)$ & 848.32 \\
Temperature / K & $100(2)$ \\
Crystal system & monoclinic \\
Space group & $\mathrm{P}_{1} / \mathrm{c}(\mathrm{No} .14)$ \\
$a / \AA$ & $12.6187(8)$ \\
$b / \AA$ & $12.2872(8)$ \\
$c / \AA$ & $23.4839(15)$ \\
$\beta /$ degree & $90.040(3)$ \\
$\mathrm{V} / \AA^{3}$ & $3641.1(4)$ \\
$\mathrm{Z}$ & 4 \\
$\mu /$ mm & -1 \\
$\theta_{\text {max }}$ & 1.727 \\
Reflections collected & 27.5 \\
Independent reflections & 141792 \\
$\mathrm{R}_{\text {int }}$ & 8349 \\
Reflections with $I>2 \sigma_{\mathrm{I}}$ & 0.040 \\
$\mathrm{R}_{1}\left(I>2 \sigma_{\mathrm{I}}\right) *$ & 7845 \\
wR $_{2}\left(I>2 \sigma_{\mathrm{I}}\right) *$ & 0.030 \\
$\mathrm{R}_{1}$ all data \\
wR $_{2}$ all data
\end{tabular}

${ }^{\mathrm{a}}$ As defined by the SHELXL program. ${ }^{40}$

D is a tetrachloroferrate(III) ion with a regular tetrahedral environment; the mean $\mathrm{Fe}-\mathrm{Cl}$ bond distance is $2.1897 \AA$. To the best of our knowledge, this was the first time the dinuclear $\left\{\mathrm{Fe}_{2}(\mu-\mathrm{Cl})_{3}\right\}^{+}$cation, also well-known in
Table 2. Selected bond lengths $(\AA)$ and angles $\left(^{\circ}\right)$ for $\left[\mathrm{Fe}_{2}(\mu-\mathrm{Cl})_{3}(\text { thf })_{6}\right]$ $\left[\mathrm{FeCl}_{4}\right],(\mathbf{D})$

\begin{tabular}{lccc}
\hline $\mathrm{Fe}(1)-\mathrm{O}(1)$ & $2.138(2)$ & $\mathrm{O}(1)-\mathrm{Fe}(1)-\mathrm{Cl}(11)$ & $176.80(6)$ \\
$\mathrm{Fe}(1)-\mathrm{O}(2)$ & $2.1048(19)$ & $\mathrm{O}(2)-\mathrm{Fe}(1)-\mathrm{Cl}(10)$ & $179.37(6)$ \\
$\mathrm{Fe}(1)-\mathrm{O}(3)$ & $2.1620(17)$ & $\mathrm{O}(3)-\mathrm{Fe}(1)-\mathrm{Cl}(12)$ & $176.84(6)$ \\
$\mathrm{Fe}(1)-\mathrm{Cl}(10)$ & $2.4483(8)$ & $\mathrm{O}(4)-\mathrm{Fe}(2)-\mathrm{Cl}(11)$ & $173.54(6)$ \\
$\mathrm{Fe}(1)-\mathrm{Cl}(11)$ & $2.4585(8)$ & $\mathrm{O}(5)-\mathrm{Fe}(2)-\mathrm{Cl}(12)$ & $174.95(6)$ \\
$\mathrm{Fe}(1)-\mathrm{Cl}(12)$ & $2.5358(6)$ & $\mathrm{O}(6)-\mathrm{Fe}(2)-\mathrm{Cl}(10)$ & $174.32(7)$ \\
$\mathrm{Fe}(2)-\mathrm{O}(4)$ & $2.129(2)$ & $\mathrm{Fe}(1)-\mathrm{Cl}(10)-\mathrm{Fe}(2)$ & $75.82(2)$ \\
$\mathrm{Fe}(2)-\mathrm{O}(5)$ & $2.1497(16)$ & $\mathrm{Fe}(1)-\mathrm{Cl}(11)-\mathrm{Fe}(2)$ & $74.90(2)$ \\
$\mathrm{Fe}(2)-\mathrm{O}(6)$ & $2.119(2)$ & $\mathrm{Fe}(2)-\mathrm{Cl}(12)-\mathrm{Fe}(1)$ & $74.214(18)$ \\
$\mathrm{Fe}(2)-\mathrm{Cl}(10)$ & $2.4611(8)$ & $\mathrm{Cl}(31)-\mathrm{Fe}(3)-\mathrm{Cl}(32)$ & $109.06(3)$ \\
$\mathrm{Fe}(2)-\mathrm{Cl}(11)$ & $2.5017(8)$ & $\mathrm{Cl}(33)-\mathrm{Fe}(3)-\mathrm{Cl}(31)$ & $109.45(4)$ \\
$\mathrm{Fe}(2)-\mathrm{Cl}(12)$ & $2.4632(6)$ & $\mathrm{Cl}(34)-\mathrm{Fe}(3)-\mathrm{Cl}(31)$ & $110.42(4)$ \\
$\mathrm{Fe}(3)-\mathrm{Cl}(31)$ & $2.1949(8)$ & $\mathrm{Cl}(33)-\mathrm{Fe}(3)-\mathrm{Cl}(32)$ & $109.84(4)$ \\
$\mathrm{Fe}(3)-\mathrm{Cl}(32)$ & $2.1966(9)$ & $\mathrm{Cl}(34)-\mathrm{Fe}(3)-\mathrm{Cl}(32)$ & $108.05(4)$ \\
$\mathrm{Fe}(3)-\mathrm{Cl}(33)$ & $2.1874(9)$ & $\mathrm{Cl}(34)-\mathrm{Fe}(3)-\mathrm{Cl}(33)$ & $110.00(4)$ \\
$\mathrm{Fe}(3)-\mathrm{Cl}(34)$ & $2.1798(9)$ & & \\
\hline
\end{tabular}

iron(II) chemistry, crystallized together with the $\left[\mathrm{FeCl}_{4}\right]^{-}$ counterion.

The X-band EPR spectrum registered for the mixture of $\mathbf{C}$ and $\mathbf{D}$ in thf solution at $77 \mathrm{~K}$ is similar to that produced by $\mathbf{A}$, presenting two main resonance lines with $\mathrm{g}=2.0$ and 4.3 and two weaker lines with $\mathrm{g}=5.4$ and 8.5 (Figure S3b). These are attributed to high spin tetrachloroferrate $(S=5 / 2)$ species solubilized in thf or alcoholic media. The complex pattern has been assigned to the coexistence of different $\left[\mathrm{FeCl}_{4}\right]^{-}$aggregates in solution, probably linked by chloride bridges, together with species generated from the interaction of the anion with the polar solvents. ${ }^{55}$

\section{Considerations on the alcoholysis reaction}

As discussed above, the isolation of $\mathbf{B}$ showed to depend not only on the relative acidities of the alcohols involved in the reaction (HOPr and HONep), but also on the partial reduction of the iron(III) centers present in the $\left[\mathrm{FeCl}_{4}\right]^{-}$counterion in $\mathbf{A}$. This reduction produces $(i)$ free chlorides in solution, (ii) at least one alcohol adduct of iron(II) and (iii) the product of alcohol oxidation (cetone from $\mathrm{Pr}^{\mathrm{i}} \mathrm{OH}$ or aldehyde from $\mathrm{NepOH}$ ). An attempt to rationalize the reaction is presented in equations 1 and 2 , using isopropoxide as reducing agent.

With $\mathrm{L}=$ alcohol: $2\left[\mathrm{Fe}^{\mathrm{III}} \mathrm{Cl}_{4}\right]^{-}+4 \mathrm{~L}+2(\mathrm{Me})_{2} \mathrm{C}(\mathrm{H}) \mathrm{O}^{-} \rightarrow 2 \mathrm{Fe}^{\mathrm{II}} \mathrm{Cl}_{2} \mathrm{~L}_{4}+4 \mathrm{Cl}^{-}+$ $\mathrm{Me}_{2} \mathrm{C}(\mathrm{O})+\mathrm{Me}_{2} \mathrm{C}(\mathrm{H}) \mathrm{OH}$ 
$\left[\mathrm{Ti}_{3}^{\mathrm{IV}}(\mathrm{O} \mathrm{Pr})_{11}\right]^{+}+\mathrm{Cl}^{-}+9 \mathrm{HONep} \rightarrow\left[\mathrm{Ti}^{\mathrm{IV}}{ }_{3}(\mathrm{O})(\mathrm{Cl})(\mathrm{ONep})_{9}\right]$

$+9 \mathrm{HO}^{\mathrm{i}} \mathrm{Pr}+\left({ }^{\mathrm{i} P r}\right)_{2} \mathrm{O}$

Reports in the literature indicate that the main product from iron(III) reduction in the presence of alcohols is the neutral complex $\left[\mathrm{FeCl}_{2}(\mathrm{HOR})_{4}\right],{ }^{58-60}$ whose formation leaves free chlorides in the reaction medium. If, on one hand, it has been not possible to isolate such product in this work, X-ray diffraction analyses of $\mathbf{B}$ showed that one isopropoxide of the $\left\{\mathrm{Ti}_{3}-\mu_{3}-\mathrm{O}^{\mathrm{i}} \mathrm{Pr}\right\}$ fragment from precursor $\mathbf{A}$ was indeed replaced by chloride. Also, a $\left[\mathrm{FeCl}_{2} \mathrm{~L}_{4}\right]$ complex such as the one suggested in equation 1 $\left(\mathrm{L}=\mathrm{HO}^{\mathrm{i}} \mathrm{Pr}\right)$ has previously been crystallized by our research group during the synthesis of $\mathbf{A}$, as a byproduct of the reaction between $\left[\mathrm{Na}\left\{\mathrm{Ti}\left(\mathrm{O}^{\mathrm{i} P r}\right)_{5}\right\}_{\infty}\right]$ and $\mathrm{FeCl}_{3}$ in toluene/isopropanol solution. ${ }^{32}$ In addition, the isolation of two iron(II)-containing products ( $\mathbf{C}$ and $\mathbf{D})$ confirms the occurrence of reduction.

The formation of the $\mu_{3}$-oxo bridge in $\mathbf{B}$ has not yet been completely understood, but the incorporation of oxo groups into reaction products is not uncommon in alkoxide systems and generally occurs through etherification, which releases the corresponding ether in solution (equation 2), or through hydrolysis of a previously formed alkoxide by small amounts of water in the reaction medium. ${ }^{48,61}$ In this context, yttrium and lanthanum oxoalkoxides with the trinuclear $\left[\mathrm{M}_{3}\left(\mu_{3}-\mathrm{O}\right)_{2}(\mu-\mathrm{OR})_{3}(\mathrm{OR})_{4} \mathrm{~L}_{2}\right]$ framework ( $\mathrm{M}=\mathrm{Y}$ or $\mathrm{La}, \mathrm{R}={ }^{\mathrm{t}} \mathrm{Bu}$ and $\mathrm{L}=\mathrm{HO}^{\mathrm{t}} \mathrm{Bu}$ or thf) have been isolated from the reaction between anhydrous $\mathrm{LnCl}_{3}$ and

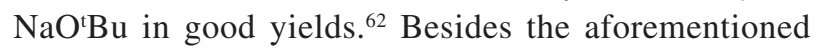
cases, several oxoalkoxides of early transition metals ${ }^{63}$ have also been prepared by well-controlled microhydrolysis involving condensation processes. . $5,47,64,65$

\section{Polymerization assays with $\varepsilon$-caprolactone}

Iniciators $\mathbf{A}$ and $\mathbf{B}$ operate through the coordinationinsertion mechanism (Figure S4) as earlier stated for other titanium alkoxides. ${ }^{36}$ This is confirmed by the comparison between the ${ }^{1} \mathrm{H}$ NMR spectra of the pure monomer and that recorded for PCL samples produced from $\mathbf{A}$ and $\mathbf{B}$. While the monomer presents signals at $\delta 2.63$ and $4.29 \mathrm{ppm}$ assigned to the methylene $\left(-\mathrm{CH}_{2}-\right)$ groups vicinal to the carbonyl atoms, these resonances are shifted to 2.34 and $4.09 \mathrm{ppm}$ in the PCL samples (Figure S5). Additionally, PCL produced with $\mathbf{B}$ as initiator showed a singlet signal at $\delta 0.94$ ppm atributed to the magnetically equivalent methyl hydrogens in the neopentyl group, $\left(\mathrm{C}_{3}\right)_{3} \mathrm{CH}_{2}-$, which is transferred from the initiator to the polymeric chain as an end group. Samples synthetized with $\mathbf{A}$, in turn, revealed signals from the terminal isopropyl groups, $\left(\mathrm{C}_{3}\right)_{2} \mathrm{CH}-$ and $\left(\mathrm{CH}_{3}\right)_{2} \mathrm{CH}-$, at 1.2 (doublet) and 5.0 (septet) ppm, respectively. The small but reproducible triplet signal at $\delta 3.7 \mathrm{ppm}$, observed in the spectra of both types of samples, was assigned to the methylene group from the other end of the PCL chain (Figure S5).

The titanium(IV) alkoxides $\mathbf{A}$ and $\mathbf{B}$ were employed as ring-opening initiators for the polymerization of $\varepsilon$-CL in toluene solution, employing a fixed $\varepsilon$-CL/initiator ratio (equal to 500), varying temperatures from 30 to $90{ }^{\circ} \mathrm{C}$ and reaction times from 8 to $24 \mathrm{~h}$. Complex $\mathbf{B}$ was also evaluated for polymerization in bulk and its results were compared with those reported earlier for $\mathbf{A} .{ }^{33}$ Titanium(IV) alkoxides have been seldom applied as initiators of $\varepsilon$-CL polymerization in toluene solution ${ }^{4}$ and, in the case of polynuclear alkoxides, very few correlations between the breakage/maintenance of the polymetallic structures and the occurrence of ROP have been established so far. Complexes A and $\mathbf{B}$ were evaluated in this work as initiators in solution in order to contribute to these studies. Selected reaction conditions and polymerization data are presented in Table 3. Initiators $\mathbf{A}$ and $\mathbf{B}$ were active in all reaction conditions, producing PCL in high yields and $\mathrm{M}_{\mathrm{n}}$ (GPC) values ranging from 3400 to $10300 \mathrm{~g} \mathrm{~mol}^{-1}$. Similar $M_{n}$ values were found for both alkoxides, with $\mathbf{B}$ leading to a better controlled process at milder reaction conditions.

Polymerization reactions performed with $\mathbf{A}$ in toluene solution at $30{ }^{\circ} \mathrm{C}$ required $24 \mathrm{~h}$ to produce PCL in high yield, but small molecular weight (up to $6500 \mathrm{~g} \mathrm{~mol}^{-1}$, Figure 4). Higher $\mathrm{M}_{\mathrm{n}}$ values $\left(9700 \mathrm{~g} \mathrm{~mol}^{-1}\right.$ ) were obtained when the temperature was increased; in this case, a shorter reaction time was necessary (entries As4 and As5 in Table 3). In contrast, $\mathbf{B}$ gave higher yields of PCL even

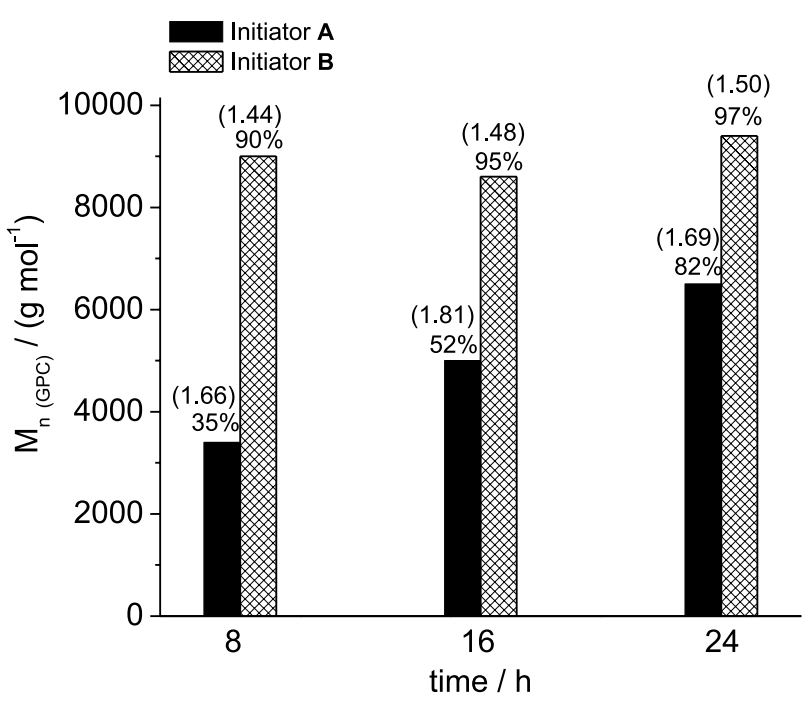

Figure 4. Variation of $M_{n}$ for PCL as a function of time (h), with an $\varepsilon$-CL/ initiator ratio equal to 500 in toluene at $30^{\circ} \mathrm{C}$. PDI values are in brackets and yields $(\%)$ are placed above each column. 
Table 3. Polymerization of $\varepsilon$ - $\mathrm{CL}$ in toluene solution (s samples) and in bulk (m samples) assisted by $\left[\mathrm{Ti}_{3}\left(\mathrm{O}^{\mathrm{i} P r}\right)_{11}\right]\left[\mathrm{FeCl}_{4}\right](\mathbf{A})$ and $\left[\mathrm{Ti}_{3}(\mathrm{O})(\mathrm{Cl})(\mathrm{ONep})_{9}\right](\mathbf{B})$

\begin{tabular}{|c|c|c|c|c|c|c|c|c|c|c|}
\hline Essays & $\mathrm{M} / \mathrm{I}^{\mathrm{a}}$ & $\mathrm{T} /{ }^{\circ} \mathrm{C}$ & time & $\begin{array}{c}\text { Conv } \alpha_{c} / \\
\%\end{array}$ & $\begin{array}{l}\text { Yield }^{\mathrm{b}} / \\
\%\end{array}$ & $\begin{array}{l}\mathrm{M}_{\text {n(theor }}{ }^{\mathrm{c}} / \\
\left(\mathrm{g} \mathrm{mol}^{-1}\right)\end{array}$ & $\begin{array}{c}\mathrm{M}_{\mathrm{n}}^{\mathrm{d}}{ }^{1} \mathrm{H} \mathrm{RMN} / \\
\quad\left(\mathrm{g} \mathrm{mol}^{-1}\right)\end{array}$ & $\begin{array}{l}\mathrm{M}_{\mathrm{n}(\mathrm{GPC})}{ }^{\mathrm{e}} / \\
\left(\mathrm{g} \mathrm{mol}^{-1}\right)\end{array}$ & $\mathrm{PDI}^{\mathrm{f}}$ & $\mathrm{N}_{\mathrm{n}}{ }^{\mathrm{g}}$ \\
\hline As1 & 500 & 30 & $8 \mathrm{~h}$ & 56 & 35 & 26820 & 4230 & 3400 & 1.66 & 7.9 \\
\hline As2 & 500 & 30 & $16 \mathrm{~h}$ & 93 & 52 & 61064 & 6897 & 5000 & 1.81 & 12 \\
\hline As3 & 500 & 30 & $24 \mathrm{~h}$ & 95 & 82 & 63347 & 9780 & 6500 & 1.69 & 9.1 \\
\hline As4 & 500 & 60 & $8 \mathrm{~h}$ & 99 & 99 & 58210 & 10260 & 9700 & 1.53 & 6.5 \\
\hline As5 & 500 & 90 & $8 \mathrm{~h}$ & 95 & 95 & 57162 & 9275 & 8000 & 1.75 & 7.2 \\
\hline Bs1 & 500 & 30 & $8 \mathrm{~h}$ & 99 & 90 & 63346 & 7695 & 9000 & 1.44 & 7.0 \\
\hline Bs2 & 500 & 30 & $16 \mathrm{~h}$ & 99 & 95 & 63346 & 7135 & 8600 & 1.48 & 7.4 \\
\hline Bs3 & 500 & 30 & $24 \mathrm{~h}$ & 99 & 97 & 63346 & 6870 & 9400 & 1.50 & 6.7 \\
\hline Bs4 & 500 & 60 & $8 \mathrm{~h}$ & 99 & 90 & 63346 & 7280 & 9300 & 1.43 & 6.8 \\
\hline Bs5 & 500 & 90 & $8 \mathrm{~h}$ & 99 & 99 & 63346 & 7540 & 9400 & 1.49 & 6.7 \\
\hline $\mathrm{Bm} 1$ & 500 & 90 & $10 \mathrm{~min}$ & 67 & 50 & 45084 & 5700 & 9900 & 1.35 & 4.6 \\
\hline $\mathrm{Bm} 2$ & 500 & 100 & $10 \mathrm{~min}$ & 89 & 80 & 57640 & 9700 & 9300 & 1.37 & 6.2 \\
\hline Bm3 & 500 & 110 & $10 \mathrm{~min}$ & 96 & 90 & 61635 & 10200 & 10300 & 1.33 & 6.0 \\
\hline $\mathrm{Bm} 4$ & 500 & 120 & $10 \mathrm{~min}$ & 94 & 90 & 60494 & 11200 & 10300 & 1.36 & 5.9 \\
\hline Bm5 & 500 & 130 & $10 \mathrm{~min}$ & 98 & 95 & 62776 & 8000 & 9400 & 1.35 & 6.7 \\
\hline
\end{tabular}

${ }^{a}$ Monomer to initiator molar ratio; byield based on the isolated amount of solid; ctheoretical molecular weight calculated from the formula: for $\mathbf{B}$, $\left[\mathrm{M}_{\mathrm{W}_{(\mathrm{CL})}} \times(\mathrm{CL} / \mathbf{B}) \times \alpha_{\mathrm{c}}\right]+89\left(89\right.$ is the molar mass of the terminal ONep groups), and for $\mathbf{A},\left[\mathrm{M}_{\mathrm{W}_{(\mathrm{CL})}} \times(\mathrm{CL} / \mathbf{A}) \times \alpha_{\mathrm{c}}\right]+60$ (60 is the molar mass of terminal

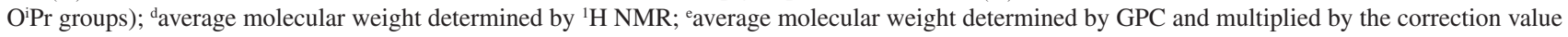
of $0.56 ;{ }^{37} \mathrm{f}$ polydispersity index determined by GPC; ${ }^{\mathrm{g}}$ calculated from $\mathrm{M}_{\mathrm{n}(\text { theor })} / \mathrm{M}_{\mathrm{n}(\mathrm{GPC})}$. It refers to the average number of growing chains per molecule of the initiator. For $\varepsilon$-CL/ initiator $=500$ and initiator concentration $=17.5 \mathrm{mmol} \mathrm{L}^{-1}$.

at low temperatures and short reaction times (entry Bs1), with $\mathbf{M}_{n}$ values similar to the ones given by $\mathbf{A}$ at higher temperatures. Also, the use of $\mathbf{B}$ produced polymers with slightly lower PDI and revealed a temperature-independent activity, since PCL samples obtained at $30{ }^{\circ} \mathrm{C}$ have the same molecular weight range of those isolated at $90{ }^{\circ} \mathrm{C}$ (9000 and $9400 \mathrm{~g} \mathrm{~mol}^{-1}$, respectively) (Table 3, entries Bs1 and Bs4-Bs5). These results suggest that, differently from $\mathbf{A}$, the activity of $\mathbf{B}$ in $\varepsilon$-CL ROP does not depend on thermal activation, and that the increase in alkoxide volume (-O'Pr to -ONep) on going from $\mathbf{A}$ to $\mathbf{B}$ helps to prevent side reactions, enabling better control of the ROP process with $\mathbf{B}$. Also, the higher Lewis basicity of the - ONep $\left(\mathrm{pKa}_{\text {HоNep }}=18\right)$ in $\mathbf{B}$ over the $-\mathrm{O}$ Pr groups in $\mathbf{A}\left(\mathrm{pKa}_{\text {HOiPr }}=17\right)^{66}$ probably favors nucleophilic attack on the $\varepsilon$-CL carbonyl groups, providing a higher affinity pathway to break the acyl-oxygen bond in the monomer during the coordination-insertion steps initiated by $\mathbf{B}$. In order to help with the analysis of these considerations, the commonly accepted anionic ROP mechanism ${ }^{10}$ is presented in Figure S4.

The better results observed with $\mathbf{B}$ in solution at lower temperatures may also be related to the longer Ti-O bonds observed for the terminal -ONep groups in B (average bond length $1.825 \AA$ ) compared to - $\mathrm{O}^{\mathrm{i}} \mathrm{Pr}$ in $\mathbf{A}$ (average
$1.758 \AA$ ) ${ }^{32}$ which could, in principle, favor the transference of the terminal alkoxide group to the polymeric chain of PCL as an end group (Figures S4 and S5). ${ }^{36}$

The bulk polymerization reactions with $\mathbf{B}$, in turn, were also conducted with an $\varepsilon$-CL/B ratio equal to 500 (according to our early report for this type of reaction),,$^{33}$ and with varying temperatures between 90 and $130^{\circ} \mathrm{C}$ (Table 3, entries $\mathbf{B m} 1$ to $\mathbf{B m 5}$ ). As a result, initiator $\mathbf{B}$ produced PCL with $\mathrm{M}_{\mathrm{n}}$ values slightly higher (9300 to $10300 \mathrm{~g} \mathrm{~mol}^{-1}$ ) and lower polydispersity indexes (below 1.4) than those obtained with $\mathbf{A}\left(\mathrm{M}_{\mathrm{n}}\right.$ of $7500 \mathrm{~g} \mathrm{~mol}^{-1}$ and PDI of ca. 1.5) in the same reaction conditions. ${ }^{33}$ Results obtained with $\mathbf{B}$ were also better than those with the simple, mononuclear alkoxide $\left[\mathrm{Ti}\left(\mathrm{O}^{\mathrm{i} P r}\right)_{4}\right]$, which gave PDI values of ca. 1.5 , but lower $\mathrm{M}_{\mathrm{n}}\left(8000 \mathrm{~g} \mathrm{~mol}^{-1}\right)$ in the same $\varepsilon$-CL/initiator ratio (500) and at $130{ }^{\circ} \mathrm{C}$ for $1 \mathrm{~h} .{ }^{33,67}$

Also, B provided a better control over the bulk polymerization process than that given by the heterometallic iron(II)/titanium(IV) $\left[\mathrm{FeCl}\left\{\mathrm{Ti}_{2}\left(\mathrm{O}^{\mathrm{P}} \mathrm{Pr}\right)_{9}\right\}\right]$ complex employed in our previous work, which gave higher PDI (1.5) and lower average $\mathrm{M}_{\mathrm{n}}$ values (8630 $\left.\mathrm{g} \mathrm{mol}^{-1}\right){ }^{34}$ In contrast, the literature reports the application of the octanuclear titanium(IV) alkoxide, $\left[\mathrm{Ti}_{8}\left(\mu_{3}-\mathrm{O}\right)_{2}(\mu-\mathrm{O})_{8}(\mathrm{O} \text { Pr })_{6}(\mathrm{O}-2,4,6-\right.$ $\left.\left.\mathrm{Br}_{3} \mathrm{C}_{6} \mathrm{H}_{2}\right)_{8}\right]$, in the ROP of $\varepsilon$-CL in similar conditions $\left(80^{\circ} \mathrm{C}\right.$ per $30 \mathrm{~min}$ ), producing polymers with a higher molar 
mass $\left(14790 \mathrm{~g} \mathrm{~mol}^{-1}\right)$ and better PDI values $(1.22)^{24}$ than those given by $\mathbf{B}$. Unfortunately the structure-reactivity relationship was not discussed in the referred work. ${ }^{4}$

Recently, a series of binuclear complexes of group 4 metals, $\left[\mathrm{M}_{2}\left(\mu-\mathrm{O}^{\mathrm{i}} \mathrm{Pr}\right)\left(\mathrm{O}^{\mathrm{i}} \mathrm{Pr}\right)_{4} \mathrm{~L}\right](\mathrm{M}=\mathrm{Ti}, \mathrm{Zr}$, Hf and $\mathrm{L}=N, N-$ di(salicylidene)-2-hydroxyphenylmethanediamine), has been tested in ROP initiation. Zirconium(IV) and hafnium(IV) complexes showed good control over the polymerization of $\varepsilon$-CL, producing polymers with low PDI values (1.21). The titanium(IV) compound, on the other hand, required $72 \mathrm{~h}$ at $80{ }^{\circ} \mathrm{C}$ to achieve $87 \%$ of monomer conversion and reach $\mathrm{M}_{\mathrm{n}}$ and PDI values of ca. $23700 \mathrm{~g} \mathrm{~mol}^{-1}$ and 1.32 , respectively. ${ }^{16}$ In this context, complex $\mathbf{B}$ shows some advantage, because it requires $8 \mathrm{~h}$ at $90{ }^{\circ} \mathrm{C}$ to reach $99 \%$ of $\varepsilon$-CL conversion in solution polymerization and $10 \mathrm{~min}$ at $100{ }^{\circ} \mathrm{C}$ to attain a conversion of $89 \%$ in bulk polymerization.

On the polynuclearity of $\mathbf{A}$ and $\mathbf{B}$ and the nature of active species

For PCL produced in this work both by solution and bulk polymerization using $\mathbf{B}$ as initiator, the molar masses determined by GPC and ${ }^{1} \mathrm{H}$ NMR are in reasonable agreement (Table 3); however, they are in fact very far from the theoretical values, $\mathrm{M}_{\mathrm{n} \text { (theor }}$, which are calculated without taking the real number of active sites in each titanium complex into account. In this context, $\mathrm{N}_{\mathrm{n}}$ data from Table 3 suggest that the nine -ONep, the $\mu_{3}-\mathrm{O}$ and the $\mu_{3}-\mathrm{Cl}$ chloride ligands present in $\mathbf{B}$ are not equally able to initiate new polymeric chains. In order to estimate the average number of active neopentoxide groups in $\mathbf{A}$ and $\mathbf{B}$ as far as the ROP process is concerned, ${ }^{68}$ the $M_{n(\text { theor })} / M_{n(G P C)}$ ratio $\left(\mathrm{N}_{\mathrm{n}}\right)$ was determined for all essays. As a result, the average $\mathrm{N}_{\mathrm{n}}$ values of 6.9 and 5.9 for polymerization by $\mathbf{B}$ in solution and in bulk, respectively, are compatible with the hypothesis that the six terminal-ONep groups are more active than the bridging ( $\left.\mu_{2}-\mathrm{ONep}\right)$, and thus primarily responsible by the PCL chain formation. Further support comes from literature reports showing the lower activity of chlorides as compared to alkoxides in the ROP process, ${ }^{67}$ as well as the following order of activity of the basic groups in polynuclear alkoxides: $-\mathrm{OR}_{\text {terminal }}>\mu_{2}-\mathrm{OR}>\mu_{3}-\mathrm{OR} . .^{21,69}$

As for $\mathbf{A}$, the average $\mathrm{N}_{\mathrm{n}}$ value of 8.5 and the large variation observed among the individual entries (As1 to As5) in Table 3 suggest a more complex behavior in toluene solution, which has already been interpreted as resulting from the gradual breakage of the polynuclear framework of A during reaction, ${ }^{32}$ generating an unknown number of lower nuclearity alkoxides capable to initiate the ROP process. Such aggregation/disaggregation equilibria are commonly observed in alkoxide chemistry and have been reported to occur in the polymerization of cyclic esters promoted by $\mathrm{Al}\left(\mathrm{O}^{\mathrm{i}} \mathrm{Pr}\right)_{3}{ }^{69}$ and $\mathrm{La}\left(\mathrm{O}^{\mathrm{i}} \mathrm{Pr}\right)_{3} \cdot{ }^{37}$ This in turn contrasts with the maintenance of the cagelike structure of $\mathbf{B}$ in solution, as indicated by results of the ${ }^{1} \mathrm{H}$ NMR analysis described earlier in this work. The higher resistance to breakage shown by $\mathbf{B}$, as compared to $\mathbf{A}$, both in toluene and in bulk, could be related to the incorporation of the $\mu_{3}-\mathrm{O}$ and $\mu_{3}-\mathrm{Cl}$ groups into the polynuclear framework, a distinctive structural feature of $\mathbf{B}$. Indeed, the average $\mathrm{Ti}-\mu_{3} \mathrm{O}_{\text {oxo }}$ bond distance in $\mathbf{B}(1.939 \AA)$ is significantly shorter than Ti- $\mu_{3} \mathrm{O}_{\text {alkoxo }}$ in $\mathbf{A}(2.156 \AA)$, implicating a stronger interaction with the metal centers. Deeper structural studies involving polynuclear alkoxides employed in ROP reactions could bring further light into this consideration.

\section{Kinetic studies in bulk polymerization}

Kinetic studies of $\varepsilon$-CL polymerization with $\mathbf{B}$ as initiator were performed in bulk to avoid possible misinterpretation due to the presence of toluene signals at $2.34 \mathrm{ppm}$ in the ${ }^{1} \mathrm{H}$ NMR spectra. These studies were also required to allow an extended comparison with kinetic data previously published for $\mathbf{A} \cdot{ }^{33}$ Reactions were carried out employing an $\varepsilon$-CL/B ratio of 500 and varying temperatures from 90 to $130^{\circ} \mathrm{C}$. Polymerization reactions were fast, taking only a few minutes for completion in all experimental conditions employed. A narrow range of $M_{n}$ results was obtained (varying from 9300 to $10300 \mathrm{~g} \mathrm{~mol}^{-1}$ ), together with lower PDI values (1.33-1.37) than those obtained in solution. These results differ from those obtained for $\mathbf{A}$ in similar conditions, which on one hand also reached high yields in less than $10 \mathrm{~min}$ in temperatures above $100{ }^{\circ} \mathrm{C}$, although at $90{ }^{\circ} \mathrm{C}$ a longer reaction time was needed. This indicates higher effectiveness of $\mathbf{B}$ compared to the observed in polymerization process assisted by $\mathbf{A} .{ }^{33}$

Similar to those observed for $\mathbf{A}$, polymerization reactions with $\mathbf{B}$ achieved quantitative conversions in $3 \mathrm{~min}$ at $110^{\circ} \mathrm{C}$. Plots of $-\ln \left(1-\alpha_{c}\right)$ as a function of time (Figure 5) and $\ln \left(\kappa_{\mathrm{p}}\right)$ versus $\mathrm{T}^{-1}$ (Figure $\mathrm{S} 6$ ), suggest a first order polymerization reaction based on monomer consumption, allowing estimation of the magnitude of the apparent propagation rate constants $\left(\kappa_{\mathrm{p}}\right) .^{36}$

Complex $\mathbf{B}$ has shown a pronounced activity towards ROP of $\varepsilon$-CL, with an induction time of about one minute observed in all polymerization essays. This is assigned to monomer coordination to the catalytic species formed in the reaction media, as also observed for $\mathbf{A}$. The values of the apparent rate constants $\left(\kappa_{\mathrm{p}}\right)$ extracted from Figure 5 
are shown in Table 4, together with those determined from $\mathbf{A}^{33}$ for comparison. These constants are significantly higher for $\mathbf{B}$, even at the lowest temperature employed, indicating that, in this case, the active species is readily formed in the reaction mixture as the initiator dissolves in the monomer. This can also be observed from the $\kappa_{\mathrm{p}}$ values at $130^{\circ} \mathrm{C}$, which are 5.8 and 32 times higher than at $90^{\circ} \mathbf{C}$ for $\mathbf{B}$ and $\mathbf{A}$, respectively (Table 4), suggesting, once more, that $\mathbf{A}$ requires thermal activation to form the active species responsible for catalyzing the ROP reaction. These higher $\kappa_{\mathrm{p}}$ values given by $\mathbf{B}$ also suggest that the -ONep ligands are more suitable nucleophiles than the isopropoxide groups in this specific reaction, as suggested earlier in this work, a proposition that finds additional support in the fact that apparent rate constants $\left(\kappa_{\mathrm{p}}\right)$ determined for $\left[\mathrm{Ti}\left(\mathrm{O}^{\mathrm{i} P r}\right)_{4}\right]$ in similar reaction conditions were close to those obtained for $\mathbf{A} .^{34}$

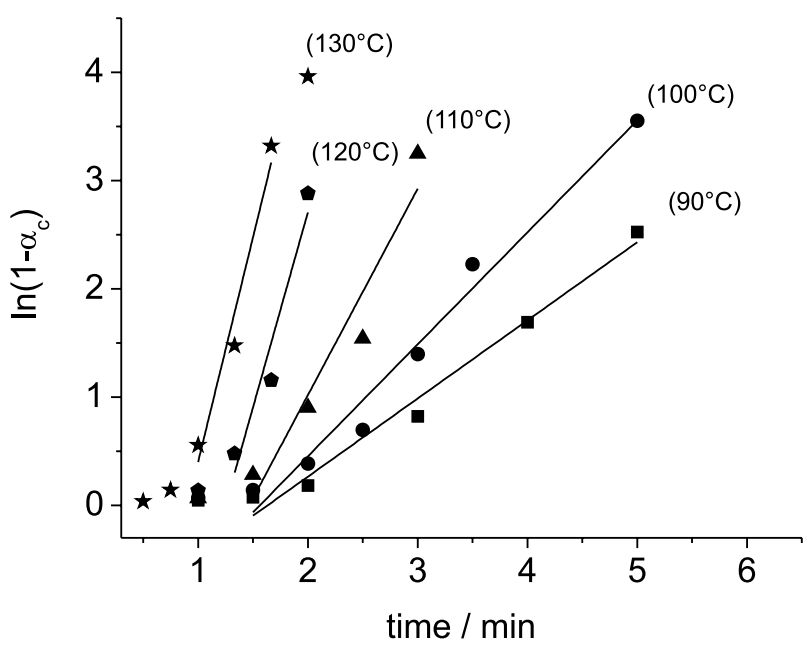

Figure 5. First order plot for $\varepsilon$-CL consumption initiated by $\mathbf{B}$ at different temperatures ( $\varepsilon-\mathrm{CL} / \mathbf{B}$ molar ratio of 500 ).

Table 4. Apparent propagation rate constants $\left(\kappa_{\mathrm{p}}\right)$ for the bulk polymerization of $\varepsilon$-CL employing $\left[\mathrm{Ti}_{3}\left(\mathrm{O}^{\mathrm{i} P r}\right)_{11}\right]\left[\mathrm{FeCl}_{4}\right](\mathbf{A})^{33}$ and $\left[\mathrm{Ti}_{3}(\mathrm{O})\right.$ $\left.(\mathrm{Cl})(\mathrm{ONep})_{9}\right](\mathbf{B})$ for a monomer/initiator ratio equal to 500

\begin{tabular}{lcc}
\hline Temperature $/{ }^{\circ} \mathrm{C}$ & $\kappa_{\mathrm{p}(\mathrm{B})} / \mathrm{min}^{-1}$ & $\left.\kappa_{\mathrm{p}(\mathrm{A})}\right)^{33} / \mathrm{min}^{-1}$ \\
\hline 90 & 0.722 & 0.146 \\
100 & 1.034 & 0.270 \\
110 & 1.906 & 0.379 \\
120 & 3.604 & 1.138 \\
130 & 4.147 & 4.610 \\
\hline
\end{tabular}

The plot in Figure $\mathrm{S} 6$ of $\ln \left(\kappa_{\mathrm{p}}\right)$ versus $\mathrm{T}^{-1}$ provides an estimation of the activation energy $\left(E_{a}\right)$ for the polymerization process. For complexes A, B and $\left[\mathrm{Ti}\left(\mathrm{O}^{\mathrm{i}} \mathrm{Pr}\right)_{4}\right]$, these calculations give $30.5,65.7$ and $57.9 \mathrm{~kJ} \mathrm{~mol}^{-1}$, respectively. ${ }^{33,34}$ Despite the experimental errors involved in this determination, these results are found to be in the same order of magnitude, as well as other $E_{a}$ values encountered for other titanium(IV) alkoxides such as $\left[\mathrm{Ti}\left(\mathrm{OC}_{8} \mathrm{H}_{17}\right)_{4}\right]$ and $\left[\mathrm{Ti}\left(\mathrm{O}^{\prime} \mathrm{Bu}\right)_{4}\right]\left(51-67\right.$ and $84-107 \mathrm{~kJ} \mathrm{~mol}^{-1}$, respectively)..$^{18}$ The higher values obtained for the tert-butyl titanium alkoxide appear to corroborate the hypothesis that the high steric requirement of this ligand $\mathrm{R}$ group impairs monomer coordination to the metal center, and therefore increases the activation energy of the ROP process. ${ }^{19}$ For $\mathbf{B}$, the presence of the $-\mathrm{CH}_{2}-$ spacer group between the oxygen donor atom and the tert-butyl ligand head may actually be one of the reasons for the better overall performance of this initiator compared to the other alkoxides mentioned in this work.

\section{Characterization of the PCL samples}

All polymeric products obtained in this work from initiators $\mathbf{A}$ and $\mathbf{B}$ showed the expected powder X-ray diffraction pattern of PCL, with high intensity peaks at $21.5,22.1$ and $23.9^{\circ}$ and small peaks at 15.8 and $30.0^{\circ}$ in $2 \theta$, assigned to the crystalline region of the PCL chains (Figure S7). ${ }^{70,71}$ The FTIR spectra registered for the solids also present the characteristic bands of PCL (Figure S8), with absorptions at 1728,1471 and $1242 \mathrm{~cm}^{-1}$ assigned to $v_{\mathrm{s}}(\mathrm{C}=\mathrm{O}), v_{\mathrm{s}}(\mathrm{C}-\mathrm{O})$ and $v_{\text {as }}(\mathrm{C}(\mathrm{C}=\mathrm{O}) \mathrm{O})$, respectively. After polymerization, the absorption band assigned to $\mathrm{V}_{\mathrm{as}}(\mathrm{C}-\mathrm{O}-\mathrm{R})$ in the monomer at $1166 \mathrm{~cm}^{-1}$ suffers a slight shift to $1182 \mathrm{~cm}^{-1}$ in the spectrum of PCL. ${ }^{72}$ Skeletal vibrations of the polymeric chain were observed in the region between 1107 and $1047 \mathrm{~cm}^{-1}$.

DSC analysis results were also as expected for PCL products, with only one melting peak for all samples analyzed, melting temperatures $\left(\mathrm{T}_{\mathrm{m}}\right)$ ranging from 53.9 to $54.1{ }^{\circ} \mathrm{C}$ and glass transition temperatures $\left(\mathrm{T}_{\mathrm{g}}\right)$ between -79.5 and $-69.5^{\circ} \mathrm{C}$ (Figure 6). The crystallinity degree of

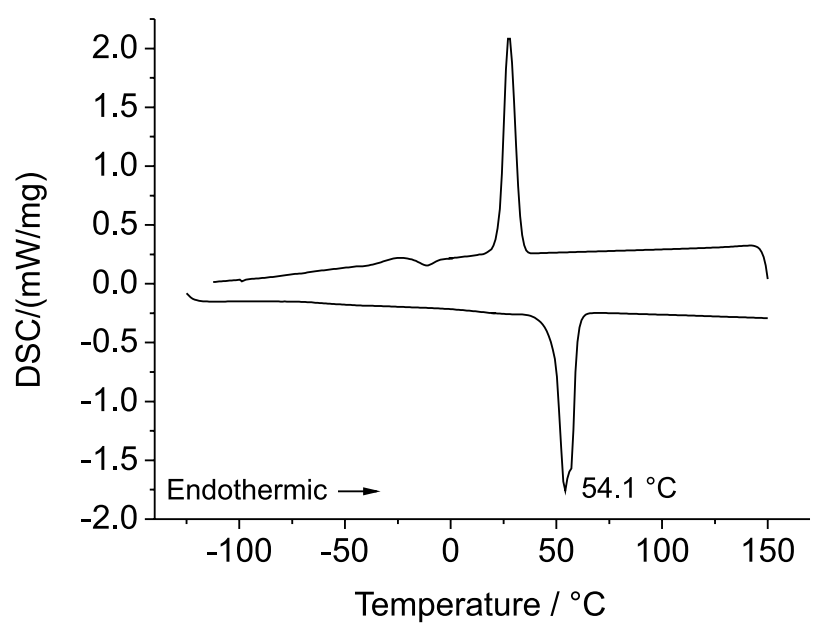

Figure 6. DSC curve registered for a representative sample of poly( $\varepsilon$ caprolactone) produced from initiator $\mathbf{B}$ in this work. 
the samples was determined in the range of 55.1 to $58.4 \%$, being in accordance with data reported in the literature. ${ }^{73}$

\section{Conclusions}

The alcoholysis reaction between $\left[\mathrm{Ti}_{3}\left(\mathrm{O}^{\mathrm{P}} \mathrm{Pr}\right)_{11}\right]\left[\mathrm{FeCl}_{4}\right](\mathbf{A})$ and neopentanol reproducibly produces the triangular alkoxide $\left[\mathrm{Ti}_{3}\left(\mu_{3}-\mathrm{O}\right)\left(\mu_{3}-\mathrm{Cl}\right)(\mu-\mathrm{ONep})_{3}(\mathrm{ONep})_{6}\right](\mathbf{B})$ in good yield and high purity. A redox process was also observed in the reaction medium, involving the alcohol and the $\left[\mathrm{FeCl}_{4}\right]^{-}$counter-ion of $\mathbf{A}$, giving $\left[\mathrm{Fe}_{4}{ }_{4} \mathrm{Cl}_{8}(\mathrm{thf})_{6}\right]$ (C), $\left[\mathrm{Fe}_{2} \mathrm{Cl}_{3}(\text { thf })_{6}\right]\left[\mathrm{FeCl}_{4}\right]$ (D) and generating free chlorides that were incorporated as $\mu_{3}-\mathrm{Cl}$ bridges in the neutral molecule of $\mathbf{B}$.

As an initiator in the ring opening polymerization of $\varepsilon$-CL, complex $\mathbf{B}$ produced PCL in milder conditions, with better reaction control and higher effectiveness than the parent alkoxide A. Reactivity enhancement with B was apparently associated with three main factors: (i) stronger Lewis basicity of the-ONep ligands compared to $-\mathrm{O}^{\text {iPr }}$ groups, (ii) presence of a $-\mathrm{CH}_{2}-$ spacer group, which makes the ligand less hindered, and (iii) longer $\mathrm{Ti}-\mathrm{O}$ bond lengths in the terminal neopentoxide groups, facilitating the nucleophilic attack to the carbonyl group of the monomer.

In spite of the complexity of titanium(IV) alkoxide chemistry in solution, our results showed that the trinuclear structure of $\mathbf{B}$, which is based on the $\left\{\mathrm{Ti}_{3}\left(\mu_{3}-\mathrm{O}\right)\left(\mu_{3}-\mathrm{Cl}\right)\right\}$ moiety, is more resistant to disaggregation than the homoleptic alkoxide A. In agreement with our previous results with $\mathbf{A}$ and $\left[\mathrm{FeCl}\left\{\mathrm{Ti}\left(\mathrm{O}^{\mathrm{i} P r}\right)_{9}\right\}\right]^{34}$ as initiators of $\varepsilon$-CL, $r a c$-LA and $L$-LA polymerization in bulk, the calculated $\mathrm{N}_{\mathrm{n}}$ values for $\mathbf{B}$ also demonstrated that the control over the polymerization processes was highly dependent on the maintenance or breakage of the polynuclear initiator structure in the reaction mixture containing the monomers. This structural feature is important because the integrity of the polynuclear framework prevents the coexistence in solution of an unknown number of active species able to initiate new PCL chains. Finally, results obtained in this work suggest that, in polynuclear alkoxides, the number of active sites may be rationally selected by the combination of active and inactive ligands in appropriate positions.

\section{Supplementary Information}

Supplementary information (Figures S1-S8 and Tables S1-S3) is available free of charge at http://jbcs.org.br as PDF file. Crystallographic data (including structure factors) for the structures in this work were deposited in the Cambridge Crystallographic Data Centre as supplementary publication numbers CCDC 1498258 and CCDC 1498259. Copies of the data can be obtained, free of charge, via www.ccdc.cam.ac.uk/conts/retrieving.html or from the Cambridge Crystallographic Data Centre, CCDC, 12 Union Road, Cambridge CB2 1EZ, UK; fax: +44 1223336033. E-mail: deposit@ccdc.cam.ac.uk.

\section{Acknowledgments}

This work was financially supported by Fundação Araucária (project number 20171010), Conselho Nacional de Desenvolvimento Científico e Tecnológico (CNPq, grant 307592/2012-0), Coordenação de Aperfeiçoamento de Pessoal de Nível Superior (CAPES, PVE A099/2013 and PNPD 2376/2011) and Universidade Federal do Paraná (UFPR). S. O. K. G., T. A. S., D. L. H., A. L. R., E. L. S., S. F. Z., J. F. S. and G. G. N. thank CNPq, CAPES and Fundação Araucária for research grants and scholarships.

\section{References}

1. Pastorino, R.; Capacchione, C.; Ferro, R.; Milione, S.; Grassi, A.; Macromolecules 2009, 42, 2480.

2. Yang, Y. K.; Yoon, S. W.; Hwang, Y. T.; Song, B. G.; Bull. Korean Chem. Soc. 2012, 33, 3445.

3. Collins, R. A.; Russell, A. F.; Mountford, P.; Appl. Petrochem. Res. 2015, 5, 153.

4. Le Roux, E.; Coord. Chem. Rev. 2016, 306, 65.

5. Nampoothiri, K. M.; Nair, N. R.; John, R. P.; Bioresour. Technol. 2010, 101, 8493 .

6. Shirazi, S. F. S.; Gharehkhani, S.; Mehrali, M.; Yarmand, H.; Metselaar, H. S. C.; Kadri, N. A.; Osman, N. A. A.; Sci. Technol. Adv. Mater. 2015, 16, 033502.

7. Mondal, D.; Griffith, M.; Venkatraman, S. S.; Int. J. Polym. Mater. Polym. Biomater. 2016, 65, 255.

8. Nyitray, C. E.; Chang, R.; Faleo, G.; Lance, K. D.; Bernards, D. A.; Tang, Q. Z.; Desai, T. A.; ACS Nano 2015, 9, 5675.

9. Darensbourg, D. J.; Karroonnirun, O.; Macromolecules 2010, 43,8880 .

10. Arbaoui, A.; Redshaw, C.; Polym. Chem. 2010, 1, 801.

11. Yildirim, I.; Crotty, S.; Loh, C. H.; Festag, G.; Weber, C.; Caponi, P. F.; Gottschaldt, M.; Westerhausen, M.; Schubert, U. S.; J. Polym. Sci., Part A: Polym. Chem. 2016, 54, 437.

12. Alhashmialameer, D.; Ikpo, N.; Collins, J.; Dawe, L. N.; Hattenhauer, K.; Kerton, F. M.; Dalton Trans. 2015, 44, 20216.

13. Sun, Y. Y.; Cui, Y. Q.; Xiong, J.; Dai, Z. R.; Tang, N.; Wu, J. C.; Dalton Trans. 2015, 44, 16383.

14. Fang, Y.-Y.; Gong, W.-J.; Shang, X.-J.; Li, H.-X.; Gao, J.; Lang, J.-P.; Dalton Trans. 2014, 43, 8282.

15. Hsieh, Y. L.; Lin, Y. C.; Lee, G. H.; Peng, C. H.; Polymer 2015, 56, 237. 
16. He, J. X.; Duan, Y. L.; Kou, X.; Zhang, Y. Z.; Wang, W.; Yang, Y.; Huang, Y.; Inorg. Chem. Commun. 2015, 61, 144.

17. Cayuela, J.; Bounor-Legare, V.; Cassagnau, P.; Michel, A.; Macromolecules 2006, 39, 1338.

18. Meelua, W.; Molloy, R.; Meepowpan, P.; Punyodom, W.; J. Polym. Res. 2012, 19, 9799.

19. Silawanich, A.; Muangpil, S.; Kungwan, N.; Meepowpan, P.; Punyodom, W.; Lawan, N.; Comput. Theor. Chem. 2016, 1090, 17.

20. Saha, T. K.; Rajashekhar, B.; Chakraborty, D.; RSC Adv. 2012, 2, 307.

21. Wang, J. F.; Yao, Y. M.; Zhang, Y.; Shen, Q.; Inorg. Chem. 2009, $48,744$.

22. Kim, Y. J.; Verkade, J. G.; Macromol. Rapid Commun. 2002, 23, 917.

23. Chuck, C. J.; Davidson, M. G.; du Sart, G. G.; Ivanova-Mitseva, P. K.; Kociok-Kohn, G. I.; Manton, L. B.; Inorg. Chem. 2013, $52,10804$.

24. Gowda, R. R.; Chakraborty, D.; Ramkumar, V.; Inorg. Chem. Commun. 2011, 14, 1777.

25. Day, V. W.; Eberspacher, T. A.; Chen, Y. W.; Hao, J. L.; Klemperer, W. G.; Inorg. Chim. Acta 1995, 229, 391.

26. Senouci, A.; Yaakoub, M.; Huguenard, C.; Henry, M.; J. Mater. Chem. 2004, 14, 3215.

27. Boyle, T. J.; Tyner, R. P.; Alam, T. M.; Scott, B. L.; Ziller, J. W.; Potter, B. G.; J. Am. Chem. Soc. 1999, 121, 12104.

28. Bashall, A.; Brown, D. A.; McPartlin, M.; Wallbridge, M. G. H.; J. Chem. Soc., Dalton Trans. 1992, 2529.

29. Boyle, T. J.; Tribby, L. J.; Alam, T. M.; Bunge, S. D.; Holland, G. P.; Polyhedron 2005, 24, 1143.

30. Andres, R.; Galakhov, M. V.; Martin, A.; Mena, M.; Santamaria, C.; Organometallics 1994, 13, 2159.

31. Nunes, G. G.; Reis, D. M.; Amorim, P. T.; Sa, E. L.; Mangrich, A. S.; Evans, D. J.; Hitchcock, P. B.; Leigh, G. J.; Nunes, F. S.; Soares, J. F.; New J. Chem. 2002, 26, 519.

32. Reis, D. M.; Nunes, G. G.; Sa, E. L.; Friedermann, G. R.; Mangrich, A. S.; Evans, D. J.; Hitchcock, P. B.; Leigh, G. J.; Soares, J. F.; New J. Chem. 2004, 28, 1168.

33. Egevardt, C.; Giese, S. O. K.; Santos, A. D. D.; Barison, A.; de As, E. L.; Zandona, A.; da Silva, T. A.; Zawadzki, S. F.; Soares, J. F.; Nunes, G. G.; J. Polym. Sci., Part A: Polym. Chem. 2014, $52,2509$.

34. Giese, S. O. K.; Egevardt, C.; Rudiger, A. L.; As, E. L.; Silva, T. A.; Zawadzki, S. F.; Soares, J. F.; Nunes, G. G.; J. Braz. Chem. Soc. 2015, 26, 2258.

35. Perrin, D. D.; Armarego, W. L.; Purification of Laboratory Chemicals, $3^{\text {rd }}$ ed.; Butterworth-Heinemann: Oxford, 1997.

36. Li, P. C.; Zerroukhi, A.; Chen, J. D.; Chalamet, Y.; Jeanmaire, T.; Xia, Z.; Polymer 2009, 50, 1109.

37. Save, M.; Schappacher, M.; Soum, A.; Macromol. Chem. Phys. 2002, 203, 889.
38. Bruker; APEX2 Software; Madison, Wisconsin, USA, 2014.

39. Sheldrick, G. M.; Acta Crystallogr., Sect. A: Found. Adv. 2008, 64, 112.

40. Sheldrick, G. M.; Acta Crystallogr., Sect. C: Struct. Chem. 2015, 71, 3 .

41. Sheldrick, G. M.; Acta Crystallogr., Sect. A: Found. Adv. 2015 , 71,3 .

42. Johnson, C. K.; Program ORTEP; Report ORNL-5138; Oak Ridge National Laboratory, Tennessee, USA, 1976.

43. Farrugia, L. J.; J. Appl. Crystallogr. 2012, 45, 849.

44. Boyle, T. J.; Alam, T. M.; Mechenbier, E. R.; Scott, B. L.; Ziller, J. W.; Inorg. Chem. 1997, 36, 3293.

45. Evans, W. J.; Ansari, M. A.; Ziller, J. W.; Polyhedron 1998, 17, 869.

46. Boyle, T. J.; Alam, T. M.; Peters, K. P.; Rodriguez, M. A.; Inorg. Chem. 2001, 40, 6281.

47. Turova, N. Y.; Turevskaya, E. P.; Kessler, V. G.; Yanovskaya, M. I.; The Chemistry of Metal Alkoxides; Springer: New York, 2002.

48. Caulton, K. G.; Hubertpfalzgraf, L. G.; Chem. Rev. 1990, 90, 969.

49. Hubert-Pfalzgraf, L. G.; Inorg. Chem. Commun. 2003, 6, 102.

50. Abrutis, A.; Hubert-Pfalzgraf, L. G.; Pasko, S. V.; Bartasyte, A.; Weiss, F.; Janickis, V.; J. Cryst. Growth 2004, 267, 529.

51. Nakamoto, K.; Infrared and Raman Spectra of Inorganic and Coordination Compounds, $5^{\text {th }}$ ed.; Wiley-Interscience: New York, 1997.

52. Kern, R. J.; J. Inorg. Nucl. Chem. 1962, 24, 1105.

53. Belskii, V. K.; Ishchenko, V. M.; Bulychev, B. M.; Protskii, A. N.; Soloveichik, G. L.; Ellert, O. G.; Seifulina, Z. M.; Rakitin, Y. V.; Novotortsev, V. M.; Inorg. Chim. Acta 1985, 96, 123.

54. Cotton, F. A.; Luck, R. L.; Son, K. A.; Inorg. Chim. Acta 1991, 179, 11.

55. Rodriguez, F.; Moreno, M.; Transition Met. Chem. 1985, 10, 108.

56. Janas, Z.; Sobota, P.; Lis, T.; J. Chem. Soc., Dalton Trans. 1991, 2429.

57. Duncan, J. S.; Nazif, T. M.; Verma, A. K.; Lee, S. C.; Inorg. Chem. 2003, 42, 1211.

58. Nunes, G. G.; Bottini, R. C. R.; Reis, D. M.; Camargo, P. H. C.; Evans, D. J.; Hitchcock, P. B.; Leigh, G. J.; As, E. L.; Soares, J. F.; Inorg. Chim. Acta 2004, 357, 1219.

59. Schembri, L.; Hoggard, P. E.; Appl. Organomet. Chem. 2014, 28,874 .

60. Rodriguez, F.; Moreno, M.; Fayet, J. C.; Varret, F.; Z. Naturforsch., A: Phys. Sci. 1983, 38, 701.

61. Doeuff, S.; Henry, M.; Sanchez, C.; Mater. Res. Bull. 1990, 25 , 1519.

62. Evans, W. J.; Sollberger, M. S.; Hanusa, T. P.; J. Am. Chem. Soc. 1988, 110, 1841. 
63. Livage, J.; Sanchez, C.; J. Non-Cryst. Solids 1992, 145, 11.

64. Steunou, N.; Bonhomme, C.; Sanchez, C.; Vaissermann, J.; Hubert-Pfalzgraf, L. G.; Inorg. Chem. 1998, 37, 901.

65. Steunou, N.; Robert, F.; Boubekeur, K.; Ribot, F.; Sanchez, C.; Inorg. Chim. Acta 1998, 279, 144.

66. Ugur, I.; Marion, A.; Parant, S.; Jensen, J. H.; Monard, G.; J. Chem. Inf. Model. 2014, 54, 2200.

67. Kim, Y.; Jnaneshwara, G. K.; Verkade, J. G.; Inorg. Chem. 2003, 42, 1437.

68. Save, M.; Soum, A.; Macromol. Chem. Phys. 2002, 203, 2591.

69. Kowalski, A.; Duda, A.; Penczek, S.; Macromolecules 1998, $31,2114$.
70. Hu, H. L.; Dorset, D. L.; Macromolecules 1990, 23, 4604.

71. Chatani, Y.; Okita, Y.; Tadokoro, H.; Yamashita, Y.; Polym. J. 1970, 1, 555.

72. Harrane, A.; Meghabar, R.; Belbachir, M.; React. Funct. Polym. 2006, 66, 1696.

73. Wang, Y. M.; Rodriguez-Perez, M. A.; Reis, R. L.; Mano, J. F.; Macromol. Mater. Eng. 2005, 290, 792.

Submitted: August 12, 2016

Published online: December 15, 2016 